\title{
137Cs in flowers, pollen and honey from the Republic of Croatia four years after the Chernobyl accident
}

\author{
D Barišić 1 , S Lulić 1 , N Kezić ${ }^{2}$, A Vertačnik 1 \\ ${ }^{1}$ Center for Marine Research, Rudjer Bošković Institute, Bijenička 54, Zagreb; \\ ${ }^{2}$ Agricultural Faculty, Zagreb, the Republic of Croatia
}

(Received 18 July 1991; accepted 7 November 1991)

\begin{abstract}
Summary $-{ }^{137} \mathrm{Cs}$ concentration was measured in flowers, pollen and honey, samples of which were collected from the Republic of Croatia 4 years after the Chernobyl accident. Radioactivity of ${ }^{137} \mathrm{Cs}$ was measured by gamma-spectrometry. Cesium in honey corresponds well with ${ }^{137} \mathrm{Cs}$ contamination of territory in the Republic of Croatia. Activity of ${ }^{137} \mathrm{Cs}$ in pollen which is higher than in honey indicates that cesium behaves analogously to potassium. The results show that equal cesium concentration in the surface soil layer results in higher cesium activities in honey in the case of meadow flowers, ie honey bee pasture, than in cases when pasture is based on bush and tree flowers. Cesium activity average in honey, collected from the Republic of Croatia territory, is $<1 \%$ of the permissible level of $600 \mathrm{~Bq} / \mathrm{kg}$.
\end{abstract}

cesium radioactivity / flower / pollen / honey / Republic of Croatia / Chernobyl

\section{INTRODUCTION}

A significant level of artificial radionuclides have been produced and have spread into the atmosphere. The main sources have been atomic weapon tests and the accident in the nuclear power plant at Chernobyl. Due to wet and dry deposition process, a great amount of artificial radionuclides have been deposited on the earth's surface as fallout.

The radioactive contamination "picture" of territory in the Republic of Croatia well known (Barišić et al, 1987a). The evaluation of radioactive contamination based on rainwater measurements corresponds to data obtained by measurements of ${ }^{137} \mathrm{Cs}$ concentrations in the surface soil layer (Barišic et al, 1987b). The assessment of deposited radionuclide movement through soil is currently of great interest due to large natural variability in radionuclide uptake by plants. Some results on ${ }^{137} \mathrm{Cs}$ distribution in the Republic of Croatia soils have been published (Barišić and Lulić, 1990).

Although human ingestion of honey is not of practical importance when considering radioactive contamination, radioactivity in honey is of particular interest when tracing radioactive contamination from fallout. The cesium which enters the soil from 
above migrates vertically with water. The migration rate of ${ }^{137} \mathrm{Cs}$ with infiltrated water can be retarded by the sorption processes. The soil's cation exchange capacity constitutes the primary determinant by which any cation will be sorbed by soil. On the other hand, it was expected that ${ }^{137} \mathrm{Cs}$ would migrate from soil to plants and food products because radionuclides, which behave like cations in soil, can move upward in the soil profile via plant uptake. Knowledge of ${ }^{137} \mathrm{Cs}$ activity in flowers, pollen and honey provides us with additional information about the contamination and cesium uptake by plants.

The area covered by the honey bees in their nectar-gathering process is scarcely more than the area of a circle with a radius of a few kilometers and the radioactivity, types and quantities of the pollen and nectar yielding plants may be determined. So the data provided are representative of a broader area.

\section{METHODS OF SAMPLING AND MEASUREMENT}

The flowers, pollen and honey samples were collected during late spring and summer 1990 from various parts of the Republic of Croatia, approximately 4 years after the Chernobyl accident. The flower samples were taken in the vicinity of honey bee hives. The pollen samples were collected with a standard pollen trap during honey bees' return to the hive while honey was sampled during extraction of honey by means of a separator. The samples were placed in plastic containers, transported to the laboratory and measured by gammaspectrometry.

The measurement of ${ }^{137} \mathrm{Cs}$ content in collected samples was made by a calibrated low background system (Ge-Li semiconductor detector coupled to a Canberra
4096 channel analyzer). The samples were counted from 20000 to $100000 \mathrm{~s}$, depending on the mass and intensity of radioactivity. Concentrations of $137 \mathrm{Cs}$ were calculated from $661.6 \mathrm{keV}$-peak. Depending on ${ }^{137} \mathrm{Cs}$ activity, counting time and mass of samples, counting error was $10 \%$ or significantly less.

\section{RESULTS}

The concentrations of ${ }^{137} \mathrm{Cs}$ in flowers are given in table I, and cesium concentrations in pollen in table II.

Table I. ${ }^{137} \mathrm{Cs}$ in flowers.

\begin{tabular}{llr} 
Location & Flower & $\begin{array}{c}{ }^{137} \mathrm{Cs} \\
(B q / \mathrm{kg} d r y \text { weight })\end{array}$ \\
\hline Zagreb & Lime-tree & 16.0 \\
Glina & Chestnut & 9.1 \\
Plitvice & Meadow flowers & 14.9 \\
Ogulin & Meadow flowers & 16.6 \\
& & \\
\hline
\end{tabular}

Table II. ${ }^{137} \mathrm{Cs}$ in pollen.

\begin{tabular}{|c|c|c|}
\hline Location & Pollen & $\begin{array}{c}{ }^{137} \mathrm{Cs} \\
\text { (Bg/kg wet mass) }\end{array}$ \\
\hline
\end{tabular}

\begin{tabular}{lllc} 
Zagreb & 1 & Meadow flowers & 34.3 \\
Zagreb & 2 & Meadow flowers & 30.2 \\
Zagreb & 3 & Meadow flowers & 32.3 \\
Ogulin & 1 & Meadow flowers & 20.1 \\
Ogulin 2 & Meadow flowers & 30.7 \\
Isl Šolta & 1 & Rosemary & 0 \\
IsI Šolta 2 & Meadow flowers & 0 \\
\hline
\end{tabular}

Isl: island. 
${ }^{137} \mathrm{Cs}$ in pollen from the Adriatic coast (the Island of Šclia) was not found. For the inland part of the Croatian territory, cesium activity in pollen is 8 to 10 times higher than in flowers (both wet mass) generally.

${ }^{137} \mathrm{Cs}$ activities in honey, together with cesium activities in various segments of vertical soil profile at the nearest measured location are shown in table III. Values of cesium activities in various segments of vertical soil profile are based on research performed during July 1986 (internal data from the Rudjer Bošković Institute laboratory for nuclear chemistry and radioecology). Additional measurements performed later at 4 locations (Filipović-Vinceković et al, 1991) showed that cesium is strongly sorbed in the top soil layer and its migration downward is a limited and relatively slow process. Cesium activity average in honey (4.6 Bq/ $\mathrm{kg}$ wet mass) is about 4.5 times less than in pollen. Similar results

Table III. ${ }^{137} \mathrm{Cs}$ in honey and soil (at nearest location).

\begin{tabular}{|c|c|c|c|c|c|c|}
\hline \multirow[t]{2}{*}{ Location } & \multirow[t]{2}{*}{ Pasture } & \multirow{2}{*}{$\begin{array}{c}{ }^{137} \mathrm{Cs} \\
\text { in honey } \\
(\mathrm{Bq} / \mathrm{kg} \text { wet mass })\end{array}$} & \multicolumn{4}{|c|}{${ }^{137} \mathrm{Cs}$ in soil } \\
\hline & & & $0-26 \mathrm{~cm}$ & $\begin{array}{r}0-5 \mathrm{~cm} \\
\text { (contamina }\end{array}$ & $\begin{array}{r}10-15 \\
n \text { in } \mathrm{KBC}\end{array}$ & $20-25 \mathrm{~cm}$ \\
\hline Zagreb & Lime-tree/meadow & 4.5 & 10.4 & 7.1 & 0.8 & 0.5 \\
\hline Glina 1 & Oil rape & 7.9 & 10.5 & 4.3 & 1.5 & 1.1 \\
\hline Glina 2 & Chestnut/meadow & 6.6 & 10.5 & 4.3 & 1.5 & 1.1 \\
\hline Voćin & Acacia & 1.3 & 10.1 & 5.1 & 1.2 & 0.8 \\
\hline P Slatina & Meadow & 3.5 & 10.1 & 5.1 & 1.2 & 0.8 \\
\hline Daruvar & Meadow & 4.8 & 13.7 & 9.4 & 1.1 & 0.4 \\
\hline G Polje & Meadow & 4.5 & 13.7 & 9.4 & 1.1 & 0.4 \\
\hline Garešnica & Acacia & 2.4 & 13.7 & 9.4 & 1.1 & 0.4 \\
\hline Bjelovar & Acacia & 0.5 & 10.6 & 7.3 & 0.8 & 0.4 \\
\hline Ogulin 1 & Lime-tree & 1.4 & 11.3 & 6.7 & 1.2 & 0.5 \\
\hline Ogulin 2 & Meadow & 3.4 & 11.3 & 6.7 & 1.2 & 0.5 \\
\hline Ogulin 3 & Meadow & 2.6 & 11.3 & 6.7 & 1.2 & 0.5 \\
\hline Medak 1 & Meadow & 5.6 & 23.3 & 17.1 & 1.5 & 0.7 \\
\hline Medak 2 & Lime-tree & 3.5 & 23.3 & 17.1 & 1.5 & 0.7 \\
\hline Udbina & Meadow & 6.0 & 23.3 & 17.1 & 1.5 & 0.7 \\
\hline Plitvice & Meadow & 5.4 & 18.9 & 13.5 & 1.3 & 0.9 \\
\hline Vrhovine & Meadow & 3.7 & 13.1 & 8.8 & 1.1 & 0.4 \\
\hline Gospić 1 & Lime-tree/meadow & 4.0 & 13.6 & 7.6 & 1.4 & 1.1 \\
\hline Gospić 2 & Meadow & 14.6 & 13.6 & 7.6 & 1.4 & 1.1 \\
\hline Gospić 3 & Meadow & 4.3 & 13.6 & 7.6 & 1.4 & 1.1 \\
\hline Gračac 1 & Heather & 3.8 & 40.6 & 32.8 & 1.7 & 0.9 \\
\hline Gračac 2 & Heather & 3.1 & 40.6 & 32.8 & 1.7 & 0.9 \\
\hline Gračac 3 & Meadow & 15.9 & 40.6 & 32.8 & 1.7 & 0.9 \\
\hline Dugi isl & Garden-sage & 0 & 6.4 & 2.3 & 1.1 & 0.6 \\
\hline Isl Šolta & Rosemary & 0.8 & 4.3 & 1.6 & 0.6 & 0.5 \\
\hline
\end{tabular}

Isl: Island. 
were published by Bunzel et al (1988) in the case of external contamination during the Chernobyl fallout period in late spring and summer 1986. About 3 times higher cesium activities were measured in flowers (dry weight) than in honey (wet weight). Results indicate that cesium behaves analogously to potassium, which was also measured, but the results of potassium determination have not been presented in this study.

From a regional point of view, the average cesium concentration in honey for northwest Croatia and the central parts of Slavonia is $4.0 \mathrm{~Bq} / \mathrm{kg}$, for the area of Lika 6.4 Bq/kg, for Gorski Kotar 2.5 Bq/kg and for the Adriatic islands $0.4 \mathrm{~Bq} . \mathrm{kg}$. These values correspond well with those for cesium contamination in the Republic of Croatia (fig 1).

Relation between cesium activities at some level in the vertical soil profile and cesium activity of $1 \mathrm{~Bq} / \mathrm{kg}$ in honey are presented in table IV together with data on honey bee pasture (type of honey). Lower cesium concentrations in surface soil layer, in cases of meadow flower bee pasture, result in equal cesium activities in honey, as well as higher cesium activities in soil in cases when bee pasture is based on acacia, lime-tree or heather flowers.

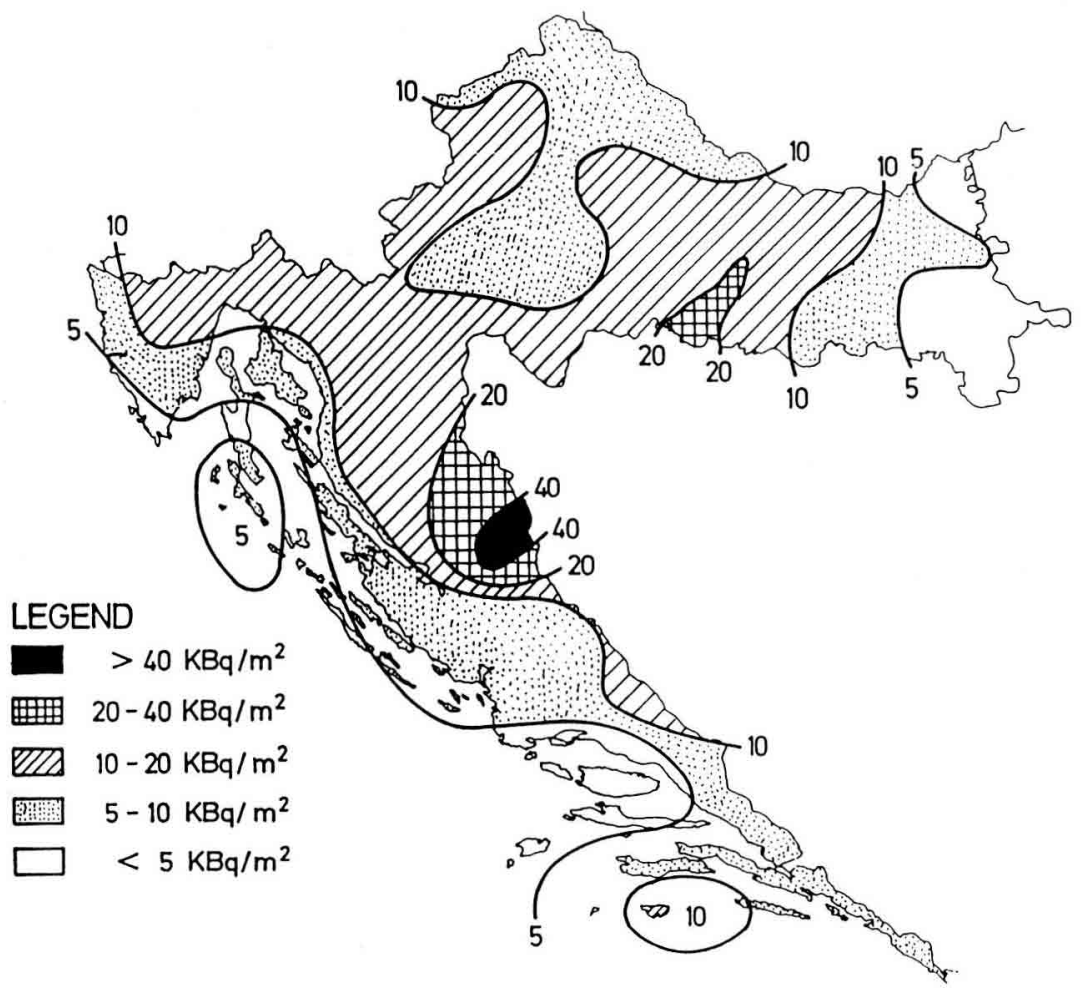

Fig $1 .{ }^{137} \mathrm{Cs}$ in soil to $26 \mathrm{~cm}$ depth. 
Table IV. Relations between cesium activities in various intervals of vertical soil profile $\left(\mathrm{KBq} / \mathrm{m}^{2}\right)$ and cesium activity of $1 \mathrm{~Bq} / \mathrm{kg}$ in honey.

\begin{tabular}{llrrrr}
\hline Location & Pasture & $0-5 \mathrm{~cm}$ & $0-10 \mathrm{~cm}$ & $0-15 \mathrm{~cm}$ & $5-15 \mathrm{~cm}$ \\
\hline & & & & & \\
\hline Zagreb & Lime-tree/meadow & 1.58 & 1.89 & 2.07 & 0.49 \\
Glina 1 & Oil rape & 0.54 & 0.84 & 1.03 & 0.48 \\
Glina 2 & Chesnut/meadow & 0.65 & 1.00 & 1.23 & 0.58 \\
Voćin & Acacia & 3.92 & 5.54 & 6.46 & 2.54 \\
P slatina & Meadow & 1.46 & 2.06 & 2.40 & 0.94 \\
Daruvar & Meadow & 1.96 & 2.42 & 2.65 & 0.69 \\
G Polje & Meadow & 2.09 & 2.58 & 2.82 & 0.73 \\
Garešnica & Acacia & 3.92 & 4.83 & 5.29 & 1.38 \\
Bjelovar & Acacia & 14.60 & 17.80 & 19.40 & 4.80 \\
Ogulin 1 & Lime-tree & 4.79 & 6.36 & 7.21 & 2.43 \\
Ogulin 2 & Meadow & 1.97 & 2.62 & 2.97 & 1.00 \\
Ogulin 3 & Meadow & 2.58 & 3.42 & 3.88 & 1.31 \\
Medak 1 & Meadow & 3.05 & 3.59 & 3.86 & 0.80 \\
Medak 2 & Lime-tree & 4.89 & 5.74 & 6.17 & 1.29 \\
Udbina & Meadow & 2.85 & 3.35 & 3.60 & 0.75 \\
Plitvice & Meadow & 2.50 & 2.91 & 3.15 & 0.65 \\
Vrhovine & Meadow & 2.38 & 2.97 & 3.27 & 0.89 \\
Gospić 1 & Lime-tree/meadow & 1.90 & 2.50 & 2.85 & 0.95 \\
Gospić 2 & Meadow & 0.52 & 0.58 & 0.78 & 0.26 \\
Gospić 3 & Meadow & 1.77 & 2.33 & 2.65 & 0.88 \\
Gračac 1 & Heather & 8.63 & 9.71 & 10.16 & 1.53 \\
Gračac 2 & Heather & 10.58 & 11.90 & 12.45 & 1.87 \\
Gračac 3 & Meadow & 2.06 & 2.32 & 2.43 & 0.36 \\
Dugi isl & Garden-sage & - & - & - & - \\
Isl Solta & Rosemary & 2.00 & 3.25 & 4.00 & 2.00 \\
& & & & & \\
\hline & & & & & \\
\hline
\end{tabular}

Isl: Island.

\section{DISCUSSION AND CONCLUSION}

Vertical transport of cesium through the soil profile is governed by water flow and geochemical retardation effects generally. The migration rate of cesium with infiltrated water can be retarted by the sorption processes, which include all physical and chemical processes which transfer dissolved matter either reversibly or irreversibly from the liquid to the solid phase. The relation between soluble and insoluble ce- sium in the soil plays one of the key roles in cesium uptake from soil by plants. The presence of soluble cesium in the soil layer with developed root systems results in the highest cesium uptake by plants.

In their nectar-gathering process, honey bees cover an area of more than $20 \mathrm{~km}^{2}$, and data on flower, pollen and honey radioactivity are very significant for understanding cesium uptake processes or/and cesium transfer from soil to food. Higher cesium activities measured in pollen than 
${ }^{137} \mathrm{Cs}$ in flowers, analogously to potassium, indicate that cesium is concentrated in particular flower parts.

On the other hand, from a regional point of view, ${ }^{137} \mathrm{Cs}$ activity in honey corresponds well to the cesium contamination in the Republic of Croatia. Correlation between honey bee pasture and ${ }^{137} \mathrm{Cs}$ activity in honey also exists. From the data given in table IV, we can conclude that about $2.5 \mathrm{KBq} / \mathrm{m}^{2}$ of ${ }^{137} \mathrm{Cs}$ in the soil layer from the surface to $10 \mathrm{~cm}$ in depth result in 1 $\mathrm{Bq} / \mathrm{kg}$ of cesium in honey in cases when honey bee pasture is based on meadow flowers. If honey bee pasture is based on bush and tree flowers, $1 \mathrm{~Bq} / \mathrm{kg}$ of cesium in honey can be expected in cases in which the contamination level of the first $10 \mathrm{~cm}$ of top soil is about $9 \mathrm{KBq} / \mathrm{m}^{2}$.

The root system of meadow flowers is shallower than that of trees or bushes so the above results are expected. Under these circumstances, absolute values of ${ }^{137} \mathrm{Cs}$ activity in honey depends only on the amount of soluble cesium in the soil. The amount of soluble cesium in the soil varies widely, depending on microconstituents and soil type. Bearing these facts in mind, it is not surprising to find higher cesium activities in honey from an area with a relatively low level of cesium contamination.

\section{ACKNOWLEDGMENTS}

We are grateful to the students of the Agricultural Faculty, University of Zagreb, especially to Saša Kapetanić, for sample collection. This research has been partly supported by the Ministry of Science, Technology and informatics of The Republic of Croatia.

Résumé - Présence de ${ }^{137}$ Cs dans les fleurs, le pollen et le miel du territoire de la République de Croatie 4 ans après l'accident de Tchernobyl. Jusqu'à présent une quantité importante de radionucléides a été produite et s'est répandue dans l'atmosphère. Parce que le dépôt se fait à la fois par la voie sèche et la voie humide, la majeure partie des radionucléides s'est déposée à la surface de la terre sous forme de retombées. Déterminer les mouvements des radionucléides dans le sol présente actuellement un grand intérêt en raison de la forte variabilité naturelle des plantes concernant l'absorption des radionucléides. Bien que l'ingestion de miel par l'homme ne représente pas un facteur important dans la contamination radioactive, la radioactivité du miel est particulièrement intéressante pour suivre la contamination radioactive due aux retombées. La migration du ${ }^{137} \mathrm{Cs}$ avec l'eau d'infiltration peut être retardée par les processus de sorption. La capacité d'échange des cations du sol représente le principal facteur par lequel les cations sont sorbés par le sol. On s'attendait par ailleurs à ce que le ${ }^{137} \mathrm{Cs}$ migre du sol dans les plantes et dans les produits alimentaires, parce que les radionucléides, qui se comportent comme des cations dans le sol, peuvent migrer vers le haut à travers le profil pédologique par l'absorption des plantes. Les échantillons de fleurs, de pollen et de miel ont été prélevés dans diverses régions du territoire de la République de Croatie environ 4 ans après l'accident de Tchernobyl. La mesure de la teneur en ${ }^{137} \mathrm{Cs}$ a été faite à l'aide d'un système calibré à faible bruit de fond (détecteur $\mathrm{Ge}-\mathrm{Li}$ semi-conducteur) en spectrométrie gamma.

L'activité du Cs dans le pollen est généralement $8-10$ fois supérieure à celle trouvée dans les fleurs, dans les deux cas mesurée en masse humide (tableaux I et II). Ceci prouve que le césium se comporte comme le potassium et se concentre particulièrement dans certaines parties florales. 
Le tableau III donne l'activité du ${ }^{137} \mathrm{Cs}$ dans le miel et celle du césium dans les différentes parties du profil pédologique, situé le plus près possible du lieu de mesure. L'activité du césium dans le miel $(4,6$ $\mathrm{Bq} / \mathrm{kg}$ de masse humide) est environ 4,5 fois plus faible que celle trouvée dans le pollen. Des résultats similaires ont été publiés par Bunzel et al (1988) dans le cas de contamination externe pendant les retombées de Tchernobyl. Sur le plan régional, la concentration moyenne du césium dans le miel est de $4,0 \mathrm{Bg} / \mathrm{kg}$ dans le Nord-Ouest de la Croatie et dans le Centre de la Slavonie, de $6,4 \mathrm{~Bq} / \mathrm{kg}$ dans la région de Lika, de 2,5 Bq/kg à Gorski Kotar et de $0,4 \mathrm{~Bq} / \mathrm{kg}$ dans les îles de l'Adriatique. Ces valeurs correspondent tout à fait à la contamination par le césium du territoire de la république de Croatie (fig 1). Pour la même activité du césium dans le miel, on constate une teneur en césium dans la couche superficielle du sol plus forte lorsque le miel provient d'une miellée d'acacia, de tilleul ou de bruyère que lorsqu'il est issu de fleurs de prairies (tableau IV). Ce résultat n'est pas surprenant, car le système racinaire des fleurs de prairies est plus superficiel que celui des arbres ou des arbrisseaux.

miel / pollen / fleur / radioactivité / césium / Tchernobyl

\section{Zusammenfassung $-137 \mathrm{Cs}$ in Blüten,} Pollen und Honig vom Territorium der Republik Kroatien vier Jahre nach dem Tschernobyl-Unfall. Bis jetzt wurde eine beträchtliche Menge von Radionukliden erzeugt und in der Atmosphäre verteilt. Als Folge von feuchten und trockenen Ablagerungsprozessen wurde die Hauptmenge der Radionuklide als Fall-out an der Erdoberfläche abgelagert. Die Feststellung der Bewegung der Radionuklide durch den Boden ist gegenwärtig wegen der großen natürlichen Variabilität der Aufnahme der Radionuklide durch Pflanzen von großem Interesse.

Obwohl bei der Bewertung der radioaktiven Kontamination der Verzehr von Honig durch den Menschen kaum von praktischer Bedeutung ist, so kommt doch der Radioaktivität des Honigs besonderes Interesse $\mathrm{zu}$, wenn man die vom Fall-out ausgehende radioaktive Kontamination verfolgt. Die Wanderungstate von ${ }^{137} \mathrm{Cs}$ mit eingedrungenem Wasser kann durch Absorptionsprozesse verlangsamt werden. Die Fähigkeit des Bodens zum Kationenaustausch stelit die primäre Größe dar, nach welcher jedes Kation durch den Boden aufgenommen wird. Andereseits war zu erwarten, daB ${ }^{137} \mathrm{Cs}$ vom Boden in die Pflanzen und Nahrungsmittel wandern wird, weil sich Radionuklide im Boden wie Kationen verhalten und sie durch das Bodenprofil über die Aufnahme durch Pflanzen nach oben wandern.

Ungefähr vier Jahre nach dem Tschernobyl-Unfall wurden in verschiedenen $\mathrm{Re}$ gionen Teilen der Republik Kroatien Proben von Blüten, Pollen und Honig gesammelt. Die Messungen des ${ }^{137} \mathrm{Cs}$ Gehalts in den Proben wurden in einem kalibrierten Low-Background-System (Ge$\mathrm{Li}$ Semiconductor Detector) nach der Gammaspektrometrie-Methode durchgeführt.

Die Caesiumaktivität war allgemein im Pollen 8 bis $10 \mathrm{mal}$ höher als in Blüten, beides in feuchter Masse gemessen ( $\mathrm{Ta}$ belle I und II). Die höhere Caesiumaktivität im Pollen im Vergleich zu Blüten, entsprechend dem Verhalten von Kalium, weist darauf hin, daß Caesium in bestimmten Blütenteilen konzentriert wird.

Die ${ }^{137}$ Cs-Aktivitäten in Honigen, zusamen mit den Caesiumaktivitäten in verschiedenen Abschnitten von vertikalen Bodenprofilen, entnommen möglichst nahe den Meßstellen, sind in Tabelle III darge- 
stellt. Die mittlere Caesium-Aktivität im Honig (4.6 Bq/kg Feuchtmasse) ist um etwa 4.5mal kleiner als die im Pollen. Ähnliche Resultate wurden von Bunzel et al (1988) im Falle der Kontamination von außen während des Tschernobyl-Fall-out veröffentlicht. Regional betrachtet, betrug die mittlere Caesiumkonzentratien im Honig in Nordwestkroation und Zentralslawonien $4.0 \mathrm{~Bq} / \mathrm{kg}$, im Gebiet von Lika 6.4 $\mathrm{Bq} / \mathrm{kg}$, in Gorski Kotar $2.5 \mathrm{~Bq} / \mathrm{kg}$ und auf den Adriatischen Inseln $0.4 \mathrm{~Bq} / \mathrm{kg}$. Diese Werte stimmen sehr gut mit der Caesiumkontamination des Territoriums der Republik Kroatien überein (fig 1).

Bei einer Caesiumkonzentration von 1.0 Bk/kg im Honig war die Caesiumkonzentration im Boden niedrig, falls die Blütentracht von Wiesen stammte; aber es wurden höhere Caesiumaktivitäten im Boden gefunden in den Fällen, wo die Bienenweide von Robinen, Linden und Heide kommt (tab IV). Das Wurzelsystem von Wiesenblumen ist flacher als das von Bäumen und Sträuchern, also war dieses Resultat zu erwarten.

\section{Honig / Pollen / Blüte / Radioaktivität / Caesium / Tschernobyl}

\section{REFERENCES}

Barišić $D$, Košutić K, Kvastek K, Lulić S, Tuta J, Vertačnik A, Vrhovac A (1987a) Procjena kontaminacije prodručja SR Hrvatske putem radioaktivnih oborina kao posljedica nesreče u NE "Lenin". XIV Jugoslav Simp za Zaštitu od Zračenja, Novi Sad 77-82 (in Croatian)

Barišić D, Košutić K, Kvastek K, Lulić S, Tuta J, Vertačnik A (1987b) Contamination of the ground surface layer in SR Croatia as a consequence of the Chernobyl accident. Proc XIVth Regional Congr Int Radiat Protect Assoc, Kupari, Dubrovnik, 219-222

Barišić D, Lulić S (1990) The contamination of ground surface layer in the Republic of Croatia as a consequence of the Chernobyl accident. Proc Int Symp Post-Chernobyl Environ Radioactivity Studies in East European Countries. Kazimierz, Poland

Bunzel K, Kracke W, Vorwohl G (1988) Transfer of Chernobyl-derived ${ }^{134} \mathrm{Cs},{ }^{137} \mathrm{Cs},{ }^{131} \mathrm{~J}$ and ${ }^{103} \mathrm{Ru}$ from flowers to honey and pollen. J Environ Radioactivity 6, 261-269

Filipović-Vinceković $N$, Barišić $D$, Mašić $N$, Lulić $S$ (1991) Distribution of fallout radionuclides through soil surface layer. $J$ Radioanal Nuclear Chem 148, 53-62 